\title{
Isolation of novel microsatellite markers for tambaqui (Colossoma macropomum, Cuvier 1818), an important freshwater fish of the Amazon
}

\author{
G. X. Santana - C. H. A. Santos - C. F. S. Sousa • \\ P. R. M. Nascimento $\cdot$ M. N. Paula-Silva • \\ A. C. B. Sousa $\cdot$ T. Campos $\cdot$ V. M. F. Almeida-Val
}

Received: 9 August 2011 / Accepted: 28 August 2011/Published online: 9 September 2011

(C) Springer Science+Business Media B.V. 2011

\begin{abstract}
Colossoma macropomum is an endemic species from Amazon basin. It is widely commercialized as food, becoming one of the main items in Amazonian fisheries. Despite its economic importance, genetic information of small captivity populations is not currently available. The present contribution describes 14 new microsatellite loci used to analyze 30 individuals of $C$. macropomum. The number of alleles for each locus ranged from 4 to 24 . The observed $(\mathrm{Ho})$ and expected $\left(H_{E}\right)$ heterozygosity values ranged from 0.318 to 1.000 and 0.729 to 0.949 , respectively. Out of 14 polymorphic loci, nine did not deviate from Hardy-Weinberg Equilibrium after Bonferroni correction. These new microsatellite loci will contribute towards the genetic of small artificial populations, as well as pedigree control of fish farms of C. macropomum.
\end{abstract}

Keywords Colossoma macropomum - Genetic diversity · Captivity $\cdot$ Polymorphism $\cdot$ Microsatellite markers

G. X. Santana - C. H. A. Santos $(\varangle) \cdot$ C.

F. S. Sousa - P. R. M. Nascimento - M. N. Paula-Silva .

V. M. F. Almeida-Val

Laboratório de Ecofisiologia e Evolução Molecular (LEEM), Instituto Nacional de Pesquisas da Amazônia (INPA), Aleixo, Manaus, AM CEP 69060-001, Brazil

e-mail: carloshenrique@inpa.gov.br

\section{A. C. B. Sousa}

Universidade do Estado da Bahia, Paulo Afonso, BA 48608-230,

Brazil

\section{T. Campos}

Empresa Brasileira de Pesquisa Agropecuária, Rio Branco, AC 69908-970, Brazil
The tambaqui, Colossoma macropomum (Cuvier, 1818), is one of the most economic important species in the region. Even though the production of this species in captivity has increased in the past few years, there are strong indications, such as the reduction in the landing of the fish in Amazonian markets and the continued reduction in the size of the fish captured, that the natural populations of tambaqui are suffering from overexploitation as reported by Isaac and Ruffino (1996) more than 10 years ago and reinforced by Araújo-Lima and Ruffino (2004) apud Santos et al. (2007). Despite its economic importance, genetic information of small captivity populations is not currently available. Since Santos et al. (2009) and Hamoy et al. (2010) described microsatellite loci from natural population, we have developed and characterized novel markers from wild and captivity populations to help the management and control of fish artificial production.

Microsatellite loci were developed from genomic enriched library following the protocol described by Billotte et al. (1999). The protocol used to total genomic DNA extracted was described by Sambrook et al. (1989). The purified total DNA was digested with Rsa I and enriched in $(\mathrm{CT})_{8}$ and $(\mathrm{GT})_{8}$ repeats. Enriched fragments were amplified by Polymerase Chain Reaction (PCR), linked into a pGem-T Easy vector (Promega) and then transformed into competent XL1-Blue Escherichia coli cells. The positive clones were selected using the $\beta$-galactosidase gene and grown overnight in an HM/FM medium with ampicillin. Plasmid DNA was purified and 96 positive clones were sequenced using T7 and SP6 primers as well as the v3.1 Big Dye terminator kit (PerkinElmer Applied Biosystems) with an ABI 377 automated DNA sequencer (Applied Biosystems). A total of 16 primers were designed using the program Oligo Explorer v 1.2 (Gene Link, Inc.) and a M13 sequence tail was added in the $5^{\prime}$ end of each forward 


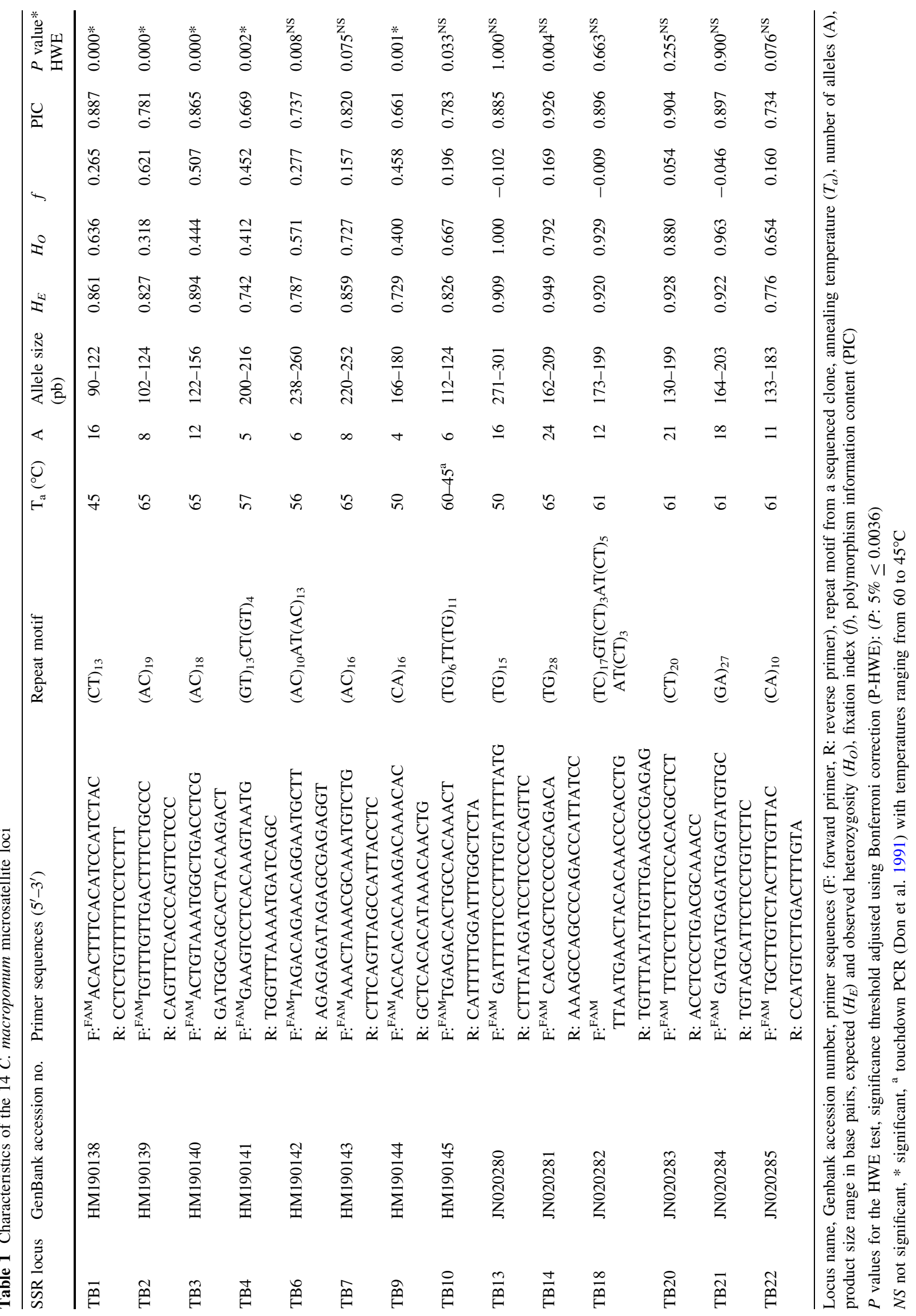


primer in order to permit the fluorescent labeling protocol suggested by Schuelke (2000).

These loci were characterized in 30 individuals of $C$. macropomum collected in lakes along Solimões River between the cities of Coari and Manaus (PIATAM Project). The microsatellite fragments were amplified by Polymerase Chain Reaction (PCR) in $10 \mu \mathrm{l}$ containing $60 \mathrm{ng}$ of genomic DNA template, each forward and M13 Label primer (FAM) at $0.4 \mu \mathrm{M}$, reverse primer at $0.8 \mu \mathrm{M}$, PCR Master Mix $(2 \times)$ (Fermentas) -0.05 units/ $\mu 1$ Taq DNA Polymerase in reaction buffer, $4 \mathrm{mM} \mathrm{MgCl}_{2}, 0.4 \mathrm{mM}$ dATP, $0.4 \mathrm{mM}$ dCTP, $0.4 \mathrm{mM}$ dGTP and $0.4 \mathrm{mM}$ dTTP. PCR was carried out with two steps: denaturation $\left(94^{\circ} \mathrm{C}\right.$, $1 \mathrm{~min}$ ) followed by 25 cycles of $20 \mathrm{~s}$ at $94^{\circ} \mathrm{C}, 20 \mathrm{~s}$ at $56^{\circ} \mathrm{C}$ (specific annealing temperature), $30 \mathrm{~s}$ at $68^{\circ} \mathrm{C}$; the second step consisted of 20 cycles with the following time and temperature profile: $20 \mathrm{~s}$ at $94^{\circ} \mathrm{C}, 20 \mathrm{~s}$ at $53^{\circ} \mathrm{C}, 30 \mathrm{~s}$ at $68^{\circ} \mathrm{C}$, and a final extension at $72^{\circ} \mathrm{C}$ for $3 \mathrm{~min}$. Amplifying products were checked by electrophoresis on $1 \%$ agarose gels containing $0.1 \mathrm{mg}$ ethidium bromide $/ \mathrm{ml}$ in $1 \times \mathrm{TBE}$ buffer $(\mathrm{pH}$ 8.0). The products from each PCR $(1.0 \mu \mathrm{l})$ were analyzed on an ABI 3130XL Sequencer and sized using the GeneScan-500 LIZ internal size standard and scored using GeneMapper version 4.0 (Applied Biosystems) software.

Out of 16 microsatellite loci developed for $C$. macropomum, 14 were polymorphic and two monomorphic. The number of alleles to estimate the observed $\left(H_{O}\right)$ and expected $\left(H_{E}\right)$ heterozygosity and fixation index $(f)$ were calculated using GDA v1.1 (Lewis and Zaykin 2000). The test for conformity to Hardy-Weinberg expectation (HWE) and Linkage Disequilibrium (LD) between all pairs of loci was calculated using Fstat v2.9.3.2 (Goudet 2001). The polymorphism information content (PIC) was calculated using CERVUS v3.0.3 (Kalinowski et al. 2007). Significance levels were adjusted to the number of simultaneous tests using sequential Bonferroni correction (Rice 1989). The number of alleles per locus ranged from 4 to 24, with an average of 11.92 alleles per locus (Table 1). Polymorphism information content (PIC) ranged from 0.661 to 0.926 . Observed heterozygosity $\left(H_{O}\right)$ and expected heterozygosity $\left(H_{E}\right)$ ranged from 0.318 to 1.000 (average 0.671 ) and 0.729 to 0.949 (average 0.852), respectively. Five loci $(T B 1, T B 2, T B 3$, $T B 4$, and TB9) showed significant deviation from the Hardy-Weinberg Equilibrium (HWE) after Bonferroni correction $(P:(5 \%)<0.0031)$. Values of $f$ ranged from -0.009 to 0.621 with average of 0.219 . The locus (TB1, $T B 2, T B 3, T B 4$, and $T B 9$ ) were significant for the presence of a null allele, as tested using the Micro-checker software (van Oosterhout et al. 2004). No significant linkage disequilibrium (LD) was detected among all loci, as analyzed using the Fstat. These results may account for no randomly mates in the analyzed populations that might be small in the sampled area. These 14 novel polymorphic microsatellite loci are highly variable and potentially useful tools for genetic studies of natural and cultured populations of $C$. macropomum.

Acknowledgments The authors are grateful to the PIATAM Project for providing the samples collected from a wild population in lakes along Solimões river between the cities of Coari and Manaus. The authors would like to thanks Coordenação de Aperfeiçoamento de Pessoal de Nível Superior (CAPES), Fundação de Amparo à Pesquisa do Amazonas (FAPEAM) and Conselho Nacional de Pesquisa (CNPq) for financial supports. CHAS is the recipient of a Ph.D. fellowship from CNPq. The Program for Academic Cooperation PROCAD between INPA/UNICAMP/UFRGS was supported by CAPES (no.023/2006/CAPES). VMFAV are the recipient of research fellowship from CNPq. This work is part of INCT ADAPTA, coordinated by Adalberto Luis Val.

\section{References}

Araújo-Lima CARM, Goulding M (2004) Migratory fishes of the Brazilian Amazon. In: Carolsfield J, Harvey B, Ross C, Baer A (eds) Migratory fishes of South America. Biology, fisheries, and conservation status. World Fisheries Trust/World Bank/IDRC, Victoria, BC, pp 233-302

Billotte N, Lagoda PJR, Risterucci AM, Baurens FC (1999) Microsatellite-enriched libraries: applied methodology for the development of SSR markers in tropical crops. Fruits 54:277288

Don RH, Cox PT, Wainwright BJ, Baker K, Mattick JS (1991) "Touchdown" PCR to circumvent spurious priming during gene amplification. Nucleic Acids Res 19(14):4008

Goudet J (2001) FSTAT, a program to estimate and test gene diversities and fixation indices. (version 2.9.3.2). Available from http://www.unil.ch/izea/softwares/fstat.html (Updated from: Goudet J (1995) FSTAT (version 1.2): a computer program to calculate F-statistics. J Hered 86: 485-486)

Hamoy IG, Cidade FW, Barbosa MS, Gonçalves EC, Santos D (2010) Isolation and characterization of tri and tetranucleotide microsatellite markers for the tambaqui (Colossoma macropomum, Serrasalmidae, Characiformes). Conserv Genet Resour 3:33-36

Isaac VJ, Ruffino ML (1996) Population dynamics of tambaqui, Colossoma macropomum Cuvier, in the lower Amazon, Brazil. Fish Manag Ecol 3:315-333

Kalinowsski ST, Taper ML, Marshall TC (2007) Revising how the computer program CERVUS accommodates genotyping error increases success in paternity assignment. Mol Ecol 16:10061099

Lewis PO, Zaykin D (2000) Genetic data analysis: computer program for the analysis of allelic Data, Version 1.1. (d15). University of Connecticut, Storrs, Connecticut

Rice WR (1989) Analyzing tables of statistical tests. Evolution 43: 223-225

Sambrook J, Fritsch EF, Maniatis T (1989) Molecular cloning: a laboratory manual, 2nd edn. Cold Spring Harbor Laboratory, New York

Santos MCF, Ruffino ML, Farias IP (2007) High levels of genetics variability and panmixia of the tambaqui Colossoma macropomum (Cuvier 1816) in the main channel of the Amazon River. J Fish Biol 71:33-44 
Santos MCF, Hrbek T, Farias IP (2009) Microsatellite markers for the tambaqui (Serrasalmidae, Characiformes), an economically important keystone species of the Amazon River floodplain. Mol Ecol Res 9:874-876

Schuelke M (2000) An economic method for the fluorescent labeling of PCR fragments. Nat Biotech 18:233-234 van Oosterhout C, Hutchinson WF, Wills DP, Shipley P (2004) Microchecker: software for identifying and correcting genotyping errors in microsatellite data. Mol Ecol Notes 4:535-538 